\title{
Geographies of Displacement: Introduction
}

\section{Claire Omhovère}

\section{(2) OpenEdition}

1 Journals

Electronic version

URL: https://journals.openedition.org/ces/4836

DOI: 10.4000/ces.4836

ISSN: 2534-6695

\section{Publisher}

SEPC (Société d'études des pays du Commonwealth)

\section{Printed version}

Date of publication: 1 April 2016

Number of pages: 5-8

ISSN: 2270-0633

\section{Electronic reference}

Claire Omhovère, "Geographies of Displacement: Introduction", Commonwealth Essays and Studies

[Online], 38.2 | 2016, Online since 05 April 2021, connection on 01 July 2021. URL: http:// journals.openedition.org/ces/4836 ; DOl: https://doi.org/10.4000/ces.4836

\section{(c) (i) () $\ominus$}

Commonwealth Essays and Studies is licensed under a Licence Creative Commons Attribution - Pas d'Utilisation Commerciale - Pas de Modification 4.0 International. 


\section{Introduction}

Back in the summer of 2009 a small group of researchers with a shared interest in the consequences of the spatial turn upon postcolonial studies decided to launch an itinerant seminar that would meet every year once in the spring at Aix-Marseille University, and the following autumn in Montpellier at Paul-Valéry University. In subsequent years, the seminar began to attract participants from neighbouring universities in Toulouse, Grenoble and Dijon who, in turn, proposed to organize sessions in their own alma mater. After four years of stimulating collegial work, we felt that the moment had come for us to take stock of the ground surveyed in our bi-annual meetings and the gain this had represented for the evolution of our research. As a result, it was thought appropriate to conclude the first cycle of the Geographies of Displacement seminar (2009-2013) by an international conference that took place on 12-14 June 2014 at PaulValéry University.

The expansion of the British Empire and its subsequent contraction and transformation into the Commonwealth was accompanied in postcolonial societies by the displacement of populations of diverse origins which, on coming into contact with each other, were transformed at the interface. The processes of exchange and transformation have given rise to original cultural productions which were the object of study of this conference, in the full diversity of their forms: literary, artistic, and cultural. For this occasion, as for the seminars that preceded it, we have adopted an interdisciplinary approach to the analysis of the ways in which migratory flows and cultural diaspora transform cultural space to the point of redefining our very conceptions of space and territorial relations. We have been sensitive to the way that a society attempts to create unitary identity and inscribe it in space from a plurality of cultural visions. Lastly, the seminars and the conference alike gave us the opportunity to review the theoretical tools and conceptual instruments available in the ever-changing fields of postcolonial and area studies (including cultural geography, ecocriticism, geocriticism, diaspora studies, geohistory, transnational history, etc.) with a view to renewing our analysis and understanding of spatial configurations. The current issue of Commonwealth Essays and Studies gathers together a selection of the papers delivered during the conference in addition to some of the presentations given in the course of the preparatory seminars. The final volume as it stands fairly reflects the complementariness of the approaches adopted by contributors to understand the historical and cultural forces that concur in giving existence to the object of our research.

Maps, in combination with the various types of discourse they elicit, are of primary importance in the articles collected for this issue. Mapping, of course, has always featured prominently in the European paraphernalia of expansion and conquest, as a necessary instrument in the process of territorialisation. This aspect is made clear in the correspondence of Allen F. Gardiner Elizabeth Rechniewski analyses. Rechniewski's essay, like Andreas Pilcher's contribution on Edwardian geography, both improve our comprehension of maps by showing that they do not simply record existing places, 
but they also create spaces in which to locate new representations. Maps are always paradoxical creations, insofar as they invent the world through the identification and the modelization of what is still unperceived in the extant. Itself a troping device, the map is then necessary to conceptualize the forces of transformation and revision that operate in cultural representations. And nowhere is this process more visible than in the widespread legal procedures that Indigenous peoples throughout the world have initiated to reclaim the territories that colonial powers confiscated when they displaced Aboriginal populations from their ancestral lands. Virginie Bernard discusses a particularly representative example of this evolution in her essay on the Noongar Aborigines of the south-west of Western Australia who lodged an application for determination of native title over their "country," in the double physical and metaphysical sense that the word possesses among the Indigenous populations of Australia. The displacements they underwent and the strategies they subsequently elaborated to relocate in their "country" led them to confront the Australian state policy of repressive authenticity that excluded them from the contemporary present. The dynamic identities the Noongars developed as a result demonstrate that all maps are strategic and that their contours are never fixed once and for all.

The historian's handling of primary sources finds its counterpart in the constantly renewed efforts of literary critics to map out the changing contours of postcolonial literature. Florence Labaune-Demeule demonstrates that attempts to do so will lead to a fresh understanding of the plasticity of the novel, and the challenges its everchanging form poses to the reader and the critic alike. Christine Vandamme retraces the successive displacements of the "Drover's Wife" - a historical icon in the formation of an Australian identity - from its inception in Henry Lawson's eponymous story to its visual embodiment in Russell Drysdale's painting and grotesque rewriting in a later short story by Murray Bail. In this respect, features like hybridity, intertextuality, and even to some degree intermediality that have long been identified as postcolonial in their manifestations - if not in their essence - can no longer be viewed as pertaining exclusively to the field. In today's global, postnational, age, such characteristics have become ubiquitous, borne as they are by the cultural flows that disseminate artistic productions through the internationalization of markets. Should we deduce from contemporary evolutions that, at some point, postcolonial literature is likely to become impossible to distinguish from a world literature increasingly written in English, its poetic strategies and political relevance dissolving into the multiplicity of voices that form the greater whole? Although none of the contributions collected in this volume could singlehandedly settle this question, there seems to be a general inclination to answer in the negative.

Diversity has been fundamental to the flourishing of postcolonial literature, first and foremost as an index of the historical context in which it developed - the size of the British Empire, the mosaic of territories, peoples and cultures it ruled over, but also the various systems of economic exploitation that were devised to adapt and adjust to changing local circumstances. Although British rule took different forms in settler-invader colonies and in plantation colonies, the literature that emerged from a common experience of displacement, subjugation and forced acculturation retains a number of shared features. 
Concern for the commonality of displacement is thus primordial in Édouard Glissant's philosophy and poetics of Relation, rooted as both are in the Caribbean islands and the experience of diaspora. In Glissant's writing, the archipelago serves as a paradigm for all forms of colonial dislocations and relocations, its geography is elevated to the status of heuristic model reconciling the experience of dispersal with the idea of system. Pascale Guibert thus clarifies the conceptual shifts through which Glissant invests the "common place" - including the topos of displacement - with new significations. The insertion of a mute hyphen between the two terms in "common-place" gives the compound a fresh articulation, since its hyphenation opens a silent yet productive space for the symbolic relations that are actively shaping the "places in progress" of the contemporary world.

There is an unmistakable Glissantian dimension to Catherine Delmas's contention that forms of historical scatterings call for a poetic gathering. Her essay compares and contrasts novels by Michael Ondaatje and Amitav Ghosh that engage with botany the collection of seeds and plant species - as an imperial enterprise, a legacy of the plantation system and a poetic trope. Delmas shows how Gosh especially experiments with the historical novel as a time-honoured medium for the recollection of collective experience, which he diverts and diffracts into myriad voices and languages to expose "the collusion between scientific, aesthetic, commercial and political interests at the core of imperialism, and the displacement of people, cultures, and languages it entails." Regarding the languages born out displacement, Chinese Pidgin English, Lascari and Creole were all used in the Indian Ocean for purposes of labour and trade in imperial times. Amitav Ghosh's reclaiming of these former badges of infamy, which he turns into an aesthetic medium for poetic creation in the Ibis Trilogy, needs to be envisaged in relation to prior literary endeavours to embrace the condition of the migrant and the displaced as an enabling position instead of a historical curse, and write from the physical and psychological disruptions displacement entails rather than against them, as Giuseppe Sofo argues in his own essay on works by Rudyard Kipling, Anita Desai and Salman Rushdie.

Even if the writers who come centre stage in Carine Davias's essay have little use for the postmodern tricks and thrills found in Ghosh's or Rushdie's novels, they are concerned, as much as the literary giants of the Indian subcontinent, with the form of collective consciousness achieved through narrative. Davias's essay introduces her research on the life narratives of Australian South Sea Islanders, the descendants of the Kanakas who were abducted 150 years ago from their original islands in the Pacific Ocean and forced to work in Queensland plantations. Their life-stories began to reach publication in the late 1970s, but so far they have received very little critical attention, although what South Sea Islanders have to say about past uprootings and the forging of a community through a shared story of resilience resonates with the worldwide experience of populations dispersed along the routes taken by labour migrations.

This volume finally insists on the multiple, often contradictory affiliations postcolonial writers and artists have been grappling with. In her own contribution, Mathilde Rogez scrutinizes the ambivalence that undermines Mark Behr's post-apartheid rewritings of the Afrikaner farm novel, or plaasroman. The plaasroman traditionally pictured the farm and its pastoral setting as a miniature empire, the beautiful and the picturesque serving as alibis for the exploitation of the land and the naturalization of spatial exclusions 
based on race. Behr's recent novels, however, are suffused with a pastoral nostalgia at variance with the ruptures the anti-plaasroman seeks to introduce with regard to the past. But bygones will not be bygones, as an Afrikaner perception of South-African history keeps surfacing in these novels through the use of Afrikaans words that convey ideological values telling a slightly different story from the account their narratives struggle to settle in English. Settling the discontents of the past, or rather putting them in perspective, is a task that the curators of the Art Gallery of New South Wales in Australia have chosen to approach in thought-provoking ways. In their collaborative essay, Angela Giovanangeli and Kim Snepvangers discuss the outcomes of the critical reflection initiated by the museum authorities on the apportioning of curatorial space. Their decision to display within the same room artworks stemming from artistic traditions that have long been perceived as irreconcilable encourages visitors to engage in an ethical dialogue with Indigenous and non-Indigenous art practices. Starting from the curatorial experience's positive results, the essay enlarges its scope to broach the pedagogical role played by Indigenous educators within Australian public institutions such as schools and universities where they are invited to contribute contents and approaches that were long ostracized from the purview of legitimate knowledge.

If we read them from a Glissantian perspective, Giovanangeli and Snepvangers encourage us to regard museums, schools and universities not merely as institutions of power, but also as common places where the postcolonial sense of the common can be critically examined, displaced and extended with a view to achieving more commonplace. Hopefully this issue of Commonwealth Essays and Studies will demonstrate that there is much to be gained from a better understanding of Glissant's philosophy of Relation. This is the reason why Pascale Guibert's scrupulous explication of its ramifications will be given a sequel with the publication of the second part of her essay in the forthcoming issue of Commonwealth Essays and Studies in the autumn of 2016.

Claire OMHOVÈRE

Paul-Valéry University - Montpellier / EMMA 